\title{
Amycolatopsis coloradensis sp. nov., the Avoparcin (LL-AV290)-Producing Strain
}

\author{
D. P. LABEDA* \\ Microbial Properties Research, National Center for Agricultural Utilization Research, \\ Agricultural Research Service, U.S. Department of Agriculture, \\ Peoria, Illinois 61604
}

\begin{abstract}
The strain that produces the glycopeptide antibiotic avoparcin (LL-AV290) has been described previously as a strain of "Streptomyces candidus." Morphological and chemotaxonomic properties of this strain are typical of the genus Amycolatopsis. The results of a study of the physiological properties of this organism and its levels of DNA relatedness to previously described Amycolatopsis species supported the decision to describe a new species for this strain, for which the name Amycolatopsis coloradensis is proposed. The type strain of $A$. coloradensis is NRRL 3218.
\end{abstract}

The genus Amycolatopsis was described by Lechevalier et al. (11) and included strains that were previously described as members of the genus Nocardia but lacked mycolic acids and contained phosphatidylethanolamine as the diagnostic phospholipid (type PII). As originally described, the genus consisted of four species, Amycolatopsis orientalis (with $A$. orientalis subsp. orientalis and $A$. orientalis subsp. lurida), Amycolatopsis mediterranei, Amycolatopsis rugosa, and Amycolatopsis sulphurea. Subsequently, Amycolatopsis azurea and Amycolatopsis fastidiosa were transferred to the genus Amycolatopsis from the genus Pseudonocardia (4). In addition, Amycolatopsis alba has been described recently (15).

Avoparcin (LL-AV290) is a vancomycin-like glycopeptide antibiotic which has been used as a growth-promoting feed additive in agricultural applications. This compound was first described by Kunstmann et al. $(5,6)$, and the microorganism which produced it, strain NRRL $3218^{\mathrm{T}}$ ( $\mathrm{T}=$ type strain), was described as a strain of "Streptomyces candidus." Chemotaxonomic studies in my laboratory have revealed that the cell walls of this strain contain the meso isomer of diaminopimelic acid rather than the LL isomer which is typical of the genus Streptomyces, as well as arabinose and galactose as diagnostic whole-cell sugars. Nocardiomycolic acids have not been found in this organism, and other chemotaxonomic markers clearly place strain NRRL $3218^{\mathrm{T}}$ in the genus $A m y$ colatopsis. In this study I compared the physiological properties of this strain with the physiological properties of previously described Amycolatopsis taxa and determined levels of DNA relatedness. The data support the proposal that a new species should be described for the avoparcin-producing strain. The name Amycolatopsis coloradensis is proposed for this organism.

\section{MATERIALS AND METHODS}

Strains, cultivation, and maintenance. All of the strains used in this study are in the Agricultural Research Service Culture Collection at the National Center for Agricultural Utilization Research in Peoria, Ill. The strains included in this study and the secondary metabolites produced by them, if known, are shown in Table 1. Primary storage of strains was as refrigerated ampoules of freeze-dried suspensions of spores and vegetative mycelia in sterile beef serum (18). Working stock cultures were maintained on ATCC medium 172 slants, which contained (per liter) $10 \mathrm{~g}$ of glucose, $20 \mathrm{~g}$ of soluble starch, $5 \mathrm{~g}$ of yeast extract, $5.0 \mathrm{~g}$ of N-Z amine (type $\mathrm{A}$ ), $1 \mathrm{~g}$ of $\mathrm{CaCO}_{3}$, and $15 \mathrm{~g}$ of agar; the $\mathrm{pH}$ of this medium was

* Mailing address: National Center for Agricultural Utilization Research, 1815 North University Street, Peoria, IL 61604. adjusted to 7.3 (2), and the cultures were stored at $4^{\circ} \mathrm{C}$ until they were needed. Biomass for extraction of DNA was grown as shaken cultures in Fernbach flasks containing ATCC medium 172 broth without calcium carbonate.

Morphological observations. Gross morphological observations were made by using cultures grown for 14 days at $28^{\circ} \mathrm{C}$ on the standard media suggested by the International Streptomyces Project (21). Micromorphology and sporulation on the same media were observed by light microscopy.

Physiological tests. Physiological tests, including tests for production of acid from carbohydrates, utilization of organic acids, and hydrolysis and decomposition of adenine, guanine, hypoxanthine, tyrosine, xanthine, casein, esculin, urea, and hippurate, were performed by using the media of Gordon et al. (3). Allantoin hydrolysis was evaluated in the basal medium suggested by Gordon et al. for esculin hydrolysis tests. Phosphatase activity was evaluated by using the method of Kurup and Schmitt (8). The temperature range for growth was determined on ATCC medium 172 agar slants (2).

Chemotaxonomy. Several chemotaxonomic properties of strain NRRL $3218^{\mathrm{T}}$ (isomer of diaminopimelic acid, whole-cell sugar content, phospholipid pattern, and menaquinone content) were determined by previously described methods ( 1 , $9,10,16)$. The fatty acid content of this organism was determined by using biomass collected from Trypticase soy broth (BBL, Cockeysville, Md.) agar plates that had been incubated for 4 days at $28^{\circ} \mathrm{C}$. Growth scraped from the plates was processed immediately or frozen at $-20^{\circ} \mathrm{C}$ until it was processed. Fatty acid methyl esters were obtained from the biomass by saponification, methylation, and extraction, using the method of Miller and Berger (17). The fatty acid methyl esters were separated and quantified by using a model 9898A gas chromatograph (Hewlett-Packard, Inc., Avondale, Pa.) equipped with a methylphenyl silicone fused silica capillary column $(25 \mathrm{~m}$ by $0.2 \mathrm{~mm}$; HewlettPackard, Inc.) and Microbial Identification System software (MIDI, Inc., Newark, Del.). Peaks were automatically integrated, and percent fatty acid content was determined by using the Microbial Identification System software.

Purification of DNA and determination of levels of relatedness. DNA was extracted by the method of Marmur (13) after cells were disrupted by passing them through a French pressure cell (SLM Instruments, Inc., Urbana, Ill.) at $10,000 \mathrm{lb} / \mathrm{in}^{2}$. The DNA was purified by hydroxylapatite chromatography or cesium chloride density gradient centrifugation (12). Individual strains generally yielded 5 to $10 \mathrm{mg}$ of DNA from 85 to $100 \mathrm{~g}$ of biomass in initial preparations. The guanine-plus-cytosine content of DNA was calculated from the thermal denaturation midpoint in $0.1 \times$ SSC $(1 \times$ SSC is $0.15 \mathrm{M}$ sodium chloride plus $0.015 \mathrm{M}$ sodium citrate), which was determined by the method of Marmur and Doty (14). The levels of DNA relatedness between strains were calculated from $C_{0} t_{05}$ values in $5 \times \mathrm{SSC}$ supplemented with $20 \%$ dimethyl sulfoxide at $65^{\circ} \mathrm{C}\left(T_{m}\right.$ $-23^{\circ} \mathrm{C}$ ) by the method of Seidler et al. $(19,20)$, as described by Kurtzman et al. (7).

Data analysis. Statistical calculations for clustering of DNA relatedness data were performed by using SAS for Windows, release 6.08 (SAS Institute Inc., Cary, N.C.) and a DTK Datatek FEAT 3300 80486-33 microcomputer. The data were clustered by the average-linkage method, using the SAS/STAT CLUSTER procedure, and a dendrogram was generated with SAS/GRAPH by using the SAS macro GRAFTREE written and kindly provided by D. Jacobs, University of Maryland.

\section{RESULTS}

Morphologically, strain NRRL $3218^{\mathrm{T}}$ is a typical member of the genus Amycolatopsis. Regular or occasional fragmentation of the aerial and substrate mycelia is observed, and no specific 
TABLE 1. Amycolatopsis strains used in this study

\begin{tabular}{lll}
\hline \multicolumn{1}{c}{ Species or subspecies } & \multicolumn{1}{c}{ Strain } & \multicolumn{1}{c}{$\begin{array}{c}\text { Metabolite(s) } \\
\text { produced }\end{array}$} \\
\hline A. alba & NRRL 18532 & Glycopeptide \\
A. azurea & NRRL 11412 & Azureomycin \\
A. coloradensis & NRRL 3218 & Avoparcin \\
A. fastidiosa & NRRL B-16697 & Antibiotic 41,494 \\
A. mediterranei & NRRL B-3240 & Rifamycins \\
A. orientalis subsp. orientalis & NRRL 2450 & Vancomycin \\
A. orientalis subsp. orientalis & NRRL B-5485 & Vancomycin \\
A. orientalis subsp. lurida & NRRL 2430 & Ristocetin \\
A. rugosa & NRRL B-2295 & Vitamin B B \\
A. sulphurea & NRRL B-2822 & Chelocardin \\
\hline
\end{tabular}

structures, such as sporangia, synnemata, or sclerotia, are produced. When aerial mycelium is produced, it is sparse and white to olive-buff. Substrate mycelium is generally yellow to orange, depending on the growth medium. A faint yellowish soluble pigment is produced on most growth media.

Strain NRRL $3218^{\mathrm{T}}$ has a typical type IV cell wall composition (meso-diaminopimelic acid, arabinose, and galactose) and a type A whole-cell sugar pattern, with arabinose and galactose as the diagnostic sugars. Mycolates are not present, and the phospholipid pattern is the typical type PII pattern, with phosphatidylethanolamine as the diagnostic nitrogencontaining phospholipid. The predominant menaquinones are type MK-9 $\left(\mathrm{H}_{2}, \mathrm{H}_{4}\right)$. The fatty acids present in strain NRRL $3218^{\mathrm{T}}$ are predominantly saturated iso acids and include 14:0 iso, $15: 0$ iso, $16: 0$ iso, and $16: 0$ iso-2-hydroxyl acids; $16: 0$ iso fatty acid methyl ester is the major component detected $(25 \%$ of the total fatty acids).

The differential physiological properties of the Amycolatopsis species which were evaluated are shown in Table 2. The physiological profile of $A$. coloradensis is distinct from the profiles of previously described species.

The levels of DNA relatedness between Amycolatopsis species are shown in Table 3 , and a dendrogram resulting from an unweighted average-linkage analysis is shown in Fig. 1. Interestingly, the strains that produce glycopeptide antibiotics form a cluster which is distinct from the strains that produce other classes of secondary metabolites. A. coloradensis NRRL $3218^{\text {T }}$ does not exhibit species level DNA homology (i.e., $>70 \%$ relatedness) with any of the other species examined.

TABLE 2. Differential physiological properties of Amycolatopsis species and subspecies

\begin{tabular}{|c|c|c|c|c|c|c|c|c|c|}
\hline Characteristic & A. coloradensis & A. alba $a^{a}$ & A. azurea & A. fastidiosa & A. mediterranei & $\begin{array}{c}\text { A. orientalis } \\
\text { subsp. orientalis }\end{array}$ & $\begin{array}{l}\text { A. orientalis } \\
\text { subsp. lurida }\end{array}$ & A. rugosa & A. sulphurea \\
\hline \multicolumn{10}{|l|}{ Decomposition of: } \\
\hline Allantoin & $-b$ & + & - & - & - & - & - & - & - \\
\hline Casein & + & + & + & + & + & + & + & + & - \\
\hline Esculin & + & + & + & + & + & + & + & + & - \\
\hline Gelatin & + & + & + & - & + & + & + & + & + \\
\hline Hypoxanthine & + & + & + & - & + & + & + & + & - \\
\hline Starch & + & + & - & - & + & + & - & - & + \\
\hline L-Tyrosine & + & + & + & + & + & + & + & $\mathbf{w}$ & + \\
\hline Urea & - & + & + & - & - & + & + & + & - \\
\hline Xanthine & - & + & + & - & - & - & + & - & - \\
\hline $\begin{array}{l}\text { Production of nitrate } \\
\text { reductase }\end{array}$ & + & - & + & + & + & - & - & - & + \\
\hline \multicolumn{10}{|l|}{ Utilization of: } \\
\hline Citrate & - & + & + & - & + & - & - & - & + \\
\hline Oxalate & - & - & + & - & w & - & - & - & - \\
\hline \multicolumn{10}{|l|}{ Acid produced from: } \\
\hline Adonitol & - & + & + & - & - & + & + & - & - \\
\hline Arabinose & - & + & + & $\mathbf{w}$ & + & + & + & + & - \\
\hline Cellobiose & + & + & + & $\mathbf{w}$ & + & + & + & - & - \\
\hline Dextrin & + & - & + & w & + & + & + & - & - \\
\hline Erythritol & - & + & + & - & - & + & + & $\mathbf{w}$ & - \\
\hline Fructose & + & + & + & + & + & + & + & - & + \\
\hline Glycerol & + & + & + & + & + & + & + & - & $w$ \\
\hline Inositol & + & + & + & - & + & + & w & - & $\mathbf{w}$ \\
\hline Lactose & - & + & + & - & + & + & + & - & - \\
\hline Maltose & - & + & + & $w$ & + & + & + & - & - \\
\hline Mannitol & + & + & + & - & + & + & + & + & + \\
\hline Melezitose & - & - & - & - & - & w & + & - & - \\
\hline Melibiose & - & + & - & - & - & - & - & - & - \\
\hline$\alpha$-Methyl-D-glucoside & + & + & + & w & - & + & w & - & - \\
\hline Raffinose & - & + & - & - & + & - & - & - & - \\
\hline Rhamnose & - & - & - & - & + & - & - & + & - \\
\hline Salicin & + & + & + & + & + & + & + & - & - \\
\hline Sorbitol & - & - & - & - & - & - & - & - & - \\
\hline Sucrose & - & - & $w$ & + & + & + & - & - & - \\
\hline Trehalose & + & + & + & + & + & + & w & - & + \\
\hline Xylose & + & + & + & + & + & + & + & + & - \\
\hline
\end{tabular}

${ }^{a}$ Data from reference 15 .

$b_{-}$, negative reaction; + , positive reaction; $w$, weak reaction. 
TABLE 3. Levels of DNA relatedness between Amycolatopsis strains

\begin{tabular}{|c|c|c|c|c|c|c|c|c|c|}
\hline \multirow[b]{2}{*}{ Strain } & \multicolumn{9}{|c|}{$\%$ DNA relatedness to: } \\
\hline & $\begin{array}{l}\text { NRRL } \\
18532^{a}\end{array}$ & $\begin{array}{l}\text { NRRL } \\
11412\end{array}$ & $\begin{array}{l}\text { NRRL } \\
3218^{\mathrm{T}}\end{array}$ & $\begin{array}{l}\text { NRRL } \\
\text { B-16697 }\end{array}$ & $\begin{array}{l}\text { NRRL } \\
\text { B-3240 }\end{array}$ & $\begin{array}{c}\text { NRRL } \\
2430\end{array}$ & $\begin{array}{c}\text { NRRL } \\
2450\end{array}$ & $\begin{array}{l}\text { NRRL } \\
\text { B-5485 }\end{array}$ & $\begin{array}{l}\text { NRRL } \\
\text { B-2295 }\end{array}$ \\
\hline A. azurea NRRL 11412 & 56 & & & & & & & & \\
\hline A. coloradensis NRRL $3218^{\mathrm{T}}$ & 27 & 33 & & & & & & & \\
\hline A. fastidiosa NRRL B-16697 & 0 & 0 & 0 & & & & & & \\
\hline A. mediterranei NRRL B-3240 & 25 & 0 & 0 & 11 & & & & & \\
\hline A. orientalis subsp. lurida NRRL 2430 & 24 & 37 & 37 & 0 & 6 & & & & \\
\hline A. orientalis subsp. orientalis NRRL 2450 & 30 & 19 & 0 & 0 & 0 & 44 & & & \\
\hline A. orientalis subsp. orientalis NRRL B- 5485 & 20 & 18 & 8 & 7 & 7 & 59 & 100 & & \\
\hline A. rugosa NRRL B-2295 & 0 & 0 & 10 & 15 & 11 & 4 & 0 & 0 & \\
\hline A. sulphurea NRRL 2822 & 0 & 0 & 0 & 7 & 0 & 0 & 0 & 21 & 0 \\
\hline
\end{tabular}

${ }^{a}$ Strain NRRL 18532 is an A. alba strain.

\section{DISCUSSION}

The results of morphological and chemotaxonomic studies of avoparcin-producing strain NRRL $3218^{\mathrm{T}}$ clearly placed this organism in the genus Amycolatopsis, since it exhibits all of the diagnostic chemotaxonomic marker characteristics of this genus. Although the glycopeptide-producing strains form a distinct genetic cluster, strain NRRL $3218^{\mathrm{T}}$ can be clearly distinguished from other taxa belonging to the genus Amycolatopsis on the basis of its physiological properties (Table 2), and the lack of species level DNA relatedness ( $>70 \%$ DNA homology) (22) confirmed the uniqueness of strain NRRL $3218^{\mathrm{T}}$. The DNA relatedness data also validated the uniqueness of $A$. alba NRRL 18532, which produces another vancomycin-like antibiotic. On the basis of the data described above, it is proposed that strain NRRL $3218^{\mathrm{T}}$ be placed in a new species, Amycola-

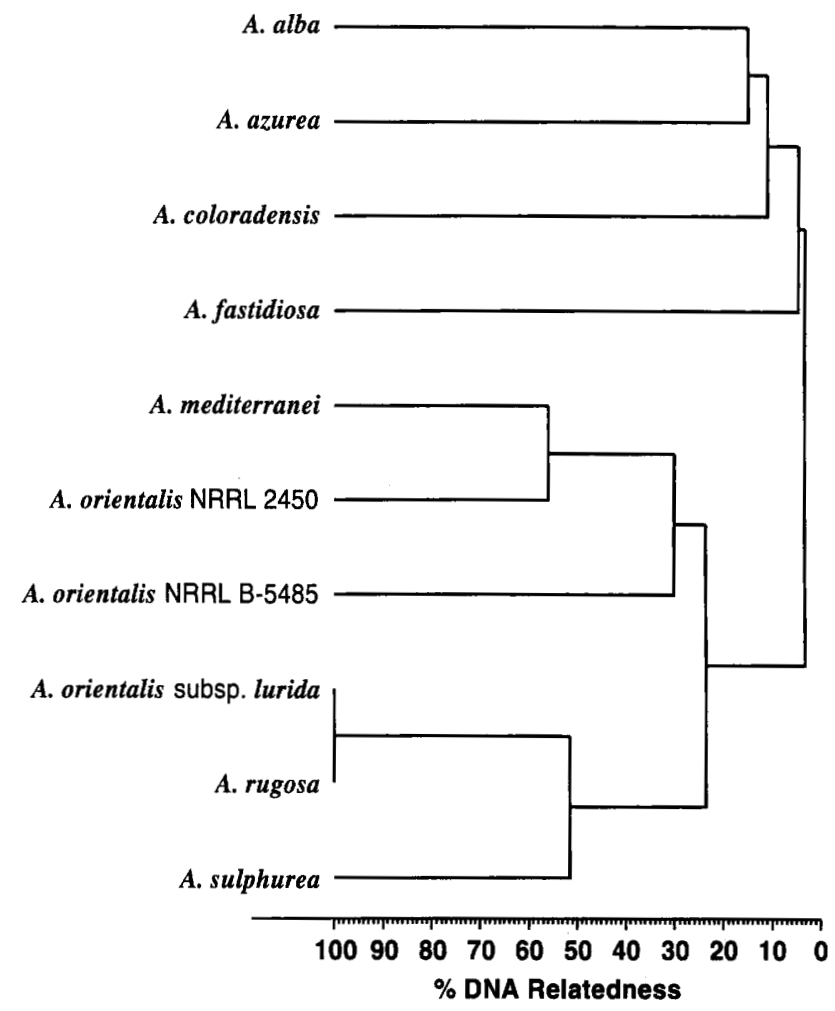

FIG. 1. Dendrogram for Amycolatopsis species based on DNA relatedness data after average-linkage clustering. topsis coloradensis. A formal description of $A$. coloradensis is given below.

Description of Amycolatopsis coloradensis sp. nov. Amycolatopsis coloradensis (co.lo.rad.en'sis. L. adj. coloradensis, of Colorado, the source of the soil sample from which the type strain was isolated). When aerial mycelium is formed, it produces cylindrical to ovoid conidia in straight to flexuous chains. Vegetative mycelium is branched. The aerial mycelium is sparse and white to olive-buff, while the substrate mycelium is yellowish to orange. A yellowish soluble pigment is produced on many growth media. Casein, esculin, gelatin, hypoxanthine, starch, and tyrosine are hydrolyzed; adenine, allantoin, urea, and xanthine are not hydrolyzed. Phosphatase and nitrate reductase are produced. Acetate, malate, propionate, pyruvate, and succinate are decarboxylated; benzoate, citrate, mucate, oxalate, and tartrate are not decarboxylated. Acid is produced from cellobiose, dextrin, fructose, galactose, glucose, glycerol, inositol, mannitol, mannose, $\alpha$-methyl-D-glucoside, salicin, trehalose, and xylose; no acid is produced from adonitol, arabinose, dulcitol, erythritol, lactose, maltose, melezitose, $\beta$-methyl-xyloside, raffinose, rhamnose, sorbitol, and sucrose. Grows at 10 to $37^{\circ} \mathrm{C}$. No growth occurs at $45^{\circ} \mathrm{C}$. Produces the glycopeptide antibiotic avoparcin (LL-AV290). Isolated from a soil sample collected in Colorado. The guanine-plus-cytosine content of the DNA is 66 mol\% (as determined by the thermal denaturation method). The type strain is strain NRRL 3218.

The DNA relatedness experiments performed with Amycolatopsis strains revealed that the levels of hybridization between all of the strains except among the vancomycin producers were low. The levels of DNA homology between the type strain of $A$. orientalis subsp. lurida and $A$. orientalis subsp. orientalis strains were only 44 to $59 \%$, and while these values are well below the species level guideline value $(70 \%$ DNA relatedness) (22), at this time there appear to be no major physiological differences that can be used to distinguish these subspecies. Until additional phenotypic and molecular systematic evaluations of $A$. orientalis strains are performed, $A$. orientalis subsp. lurida should probably remain a subspecies.

\section{ACKNOWLEDGMENTS}

Appreciation is expressed to E. N. Hoekstra, K. Kudek, and J. Lawton for technical assistance in this study.

\section{REFERENCES}

1. Collins, M. D., T. Pirouz, M. Goodfellow, and D. E. Minnikin. 1977 Distribution of menaquinones in actinomycetes and corynebacteria. J. Gen. Microbiol. 100:221-230.

2. Cote, R., P.-M. Daggett, M. J. Gantt, R. Hay, S.-C. Hay, and P. Pienta. 1984 
ATCC media handbook, 1st ed. American Type Culture Collection, Rockville, Md.

3. Gordon, R. E., D. A. Barnett, J. E. Handerhan, and C. Pang. 1974. Nocardia coeliaca, Nocardia autotrophica, and the nocardin strain. Int. J. Syst. Bacteriol. 24:54-63.

4. Hensen, A., H. W. Kothe, and R. M. Kroppenstedt. 1987. Transfer of Pseudonocardia azurea and Pseudonocardia fastidiosa to the genus Amycolatopsis, with emended species descriptions. Int. J. Syst. Bacteriol. 37:292-295.

5. Kunstmann, M. P., L. A. Mischer, J. N. Porter, A. J. Shay, and M. A. Darken. 1969. LL-AV290, a new antibiotic. I. Fermentation, isolation, and characterization, p. 242-245. Antimicrob. Agents Chemother. 1968.

6. Kunstmann, M. P., and J. N. Porter. August 1967. Antibiotic AV290 and production thereof. U.S. patent 3,338,786.

7. Kurtzman, C. P., M. J. Smiley, C. J. Johnson, L. J. Wickerham, and G. B. Fuson. 1980. Two new and closely related heterothallic species, Pichia amylophila and Pichia mississippiensis: characterization by hybridization and deoxyribonucleic acid reassociation. Int. J. Syst. Bacteriol. 30:208-216.

8. Kurup, P. V., and J. A. Schmitt. 1973. Numerical taxonomy of Nocardia. Can. J. Microbiol. 19:1035-1048.

9. Lechevalier, M. P., C. DeBièvre, and H. A. Lechevalier. 1977. Chemotax onomy of aerobic actinomycetes: phospholipid composition. Biochem. Syst. Ecol. 5:249-260.

10. Lechevalier, M. P., and H. A. Lechevalier. 1980. The chemotaxonomy of actinomycetes, p. 227-291. In A. Dietz and D. W. Thayer (ed.), Actinomycete taxonomy. Special publication no. 6. Society for Industrial Microbiology, Arlington, Va.

11. Lechevalier, M. P., H. Prauser, D. P. Labeda, and J.-S. Ruan. 1986. Two new genera of nocardioform actinomycetes: Amycolata gen. nov. and Amycolatopsis gen. nov. Int. J. Syst. Bacteriol. 36:29-37.

12. Maniatis, T., E. F. Fritsch, and J. Sambrook. 1982. Molecular cloning: a laboratory manual. Cold Spring Harbor Laboratory, Cold Spring Harbor, N.Y.
13. Marmur, J. 1961. A procedure for the isolation of deoxyribonucleic acid from microorganisms. J. Mol. Biol. 3:208-218.

14. Marmur, J., and P. Doty. 1962. Determination of the base composition of deoxyribonucleic acid from its thermal denaturation temperature. J. Mol. Biol. 5:109-118.

15. Mertz, F. P., and R. C. Yao. 1993. Amycolatopsis alba sp. nov., isolated from soil. Int. J. Syst. Bacteriol. 43:715-720.

16. Meyertons, J. L., D. P. Labeda, G. L. Cote, and M. P. Lechevalier. 1988. A new thin-layer chromatographic method for whole-cell sugar analysis of Micromonospora species. Actinomycetes 20:182-192.

17. Miller, L., and T. Berger. 1985. Bacterial identification by gas chromotog. raphy of whole cell fatty acids. Hewlett-Packard Application Note 228-41. Hewlett-Packard Co., Avondale, $\mathrm{Pa}$.

18. Pridham, T. G., and A. J. Lyons. 1980. Methodologies for Actinomycetales with special reference to streptomycetes and streptoverticillia, p. 153-224. In A. Dietz, and D. W. Thayer (ed.), Actinomycete taxonomy. Special publication no. 6. Society for Industrial Microbiology, Arlington, Va.

19. Seidler, R. J., M. D. Knittel, and C. Brown. 1975. Potential pathogens in the environment: cultural reactions and nucleic acid studies on Klebsiella pneumoniae from chemical and environmental sources. Appl. Microbiol. 29:819825.

20. Seidler, R. J., and M. Mandel. 1971. Quantitative aspects of deoxyribonucleic acid renaturation: base composition, state of chromosome replication, and polynucleotide homologies. J. Bacteriol. 106:608-614.

21. Shirling, E. B., and D. Gottleib. 1966. Methods for characterization of Streptomyces species. Int. J. Syst. Bacteriol, 16:313-340.

22. Wayne, L. G., D. J. Brenner, R. R. Colwell, P. A. D. Grimont, O. Kandler, M. I. Krichevsky, L. H. Moore, W. E. C. Moore, R. G. E. Murray, E. Stackebrandt, M. P. Starr, and H. G. Truper. 1987. Report of the Ad Hoc Committee on Reconciliation of Approaches to Bacterial Systematics. Int. J. Syst. Bacteriol. 37:463-464 